\title{
Adenovirus-Mediated Transfer of the CFTR Gene to Lung of Nonhuman Primates: Toxicity Study
}

\author{
RICHARD H. SIMON, ${ }^{1}$ JOHN F. ENGELHARDT,${ }^{2}$ YIPING YANG,${ }^{2}$ MONICA ZEPEDA, ${ }^{2}$ \\ SARA WEBER-PENDLETON, ${ }^{1}$ MARIANN GROSSMAN,${ }^{2}$ and JAMES M. WILSON ${ }^{2}$
}

\begin{abstract}
In preparation for human trials of gene therapy for cystic fibrosis (CF), we performed a preclinical study of gene transfer into the lungs of baboons. Recombinant adenovirus vectors containing expression cassettes for human cystic fibrosis transmembrane conductance regulator (CFTR) and Escherichia coli $\beta$-galactosidase (lacZ) were instilled through a bronchoscope into limited regions of lung in 14 baboons. A detailed accounting of the extent, distribution, and duration of gene expression is contained in a companion article (Engelhardt et al., 1993b). In this article, we report the results of toxicity studies in which clinical laboratory tests, chest radiographs, and necropsy studies were used to detect adverse effects. The only adverse effect noted was a mononuclear cell inflammatory response within the alveolar compartment of animals receiving doses of virus that were required to induce detectable gene expression. Minimal inflammation was seen at $10^{7}$ and $10^{8} \mathrm{pfu} / \mathrm{ml}$, but at $10^{9}$ and more prominently at $10^{10} \mathrm{pfu} / \mathrm{ml}$, a perivascular lymphocytic and histocytic infiltrate was seen. The intensity of inflammation increased between 4 and 21 days. At its greatest intensity, there was diffuse alveolar wall damage with intra-alveolar edema. Airways were relatively spared, despite the intensity of alveolar inflammation. Clinical tests did not accurately reflect the presence of lung inflammation, with the exception of chest radiographs which revealed alveolar infiltrates, but only in regions of lung having the greatest intensity inflammation. We conclude that adenovirus-mediated gene transfer into the lungs of baboons is associated with development of alveolar inflammation at high doses of virus.
\end{abstract}

\section{OVERVIEW SUMMARY}

Experiments in small animals support the feasibility of recombinant adenoviruses for treating $\mathrm{CF}$ lung disease. Studies in nonhuman primates are critical in assessing the potential toxicities associated with these therapies. In a series of two papers, Wilson and colleagues have simulated the general construct of a phase $I$ trial in baboons to evaluate the feasibility and safety of recombinant adenoviruses for gene therapy of CF lung disease. This paper by Simon $e t a l$, evaluates the clinical and pathological consequences of direct instillation of CFTR expressing adenoviruses in the airway of baboons.

\section{INTRODUCTION}

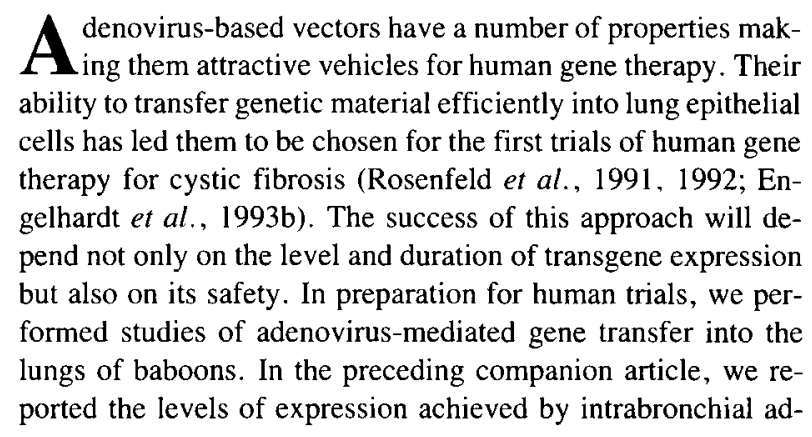

A enovirus-based vectors have a number of properties making them attractive vehicles for human gene therapy. Their ability to transfer genetic material efficiently into lung epithelial cells has led them to be chosen for the first trials of human gene therapy for cystic fibrosis (Rosenfeld et al., 1991, 1992; Engelhardt et al., 1993b). The success of this approach will depend not only on the level and duration of transgene expression but also on its safety. In preparation for human trials, we performed studies of adenovirus-mediated gene transfer into the ported the levels of expression achieved by intrabronchial ad-

'Department of Internal Medicine, University of Michigan Medical Center, Ann Arbor, MI 48109.

${ }^{2}$ Institute for Human Gene Therapy, University of Pennsylvania Medical Center, and Wistar Institute, Philadelphia, PA 19104. 
ministration of the cystic fibrosis transmembrane conductance regulator (CFTR) gene and a reporter gene (lacZ) using adenoviral vectors (Engelhardt et al., 1993b). As part of the study design, we monitored the animals for the appearance of adverse effects. In this article, we report that transgene expression in the lung was associated with the development of an inflammatory reaction within the alveolar space.

\section{METHODS}

\section{General study design}

The preceding companion article (Engelhardt et al., 1993b) contains details of the experimental protocols used for these studies; Table 1 summarizes the general structure of the experiments and salient features of the baboons. As a general description of the study, 14 baboons were used, including 2 adults for preliminary studies and 12 adolescent baboons in a dose-response trial. In study I, a single animal (B I) received intrabronchial instillation of Ad.CMVlacZ $\left(10^{10} \mathrm{pfu} / \mathrm{ml}\right)$ into the posterior segment of the left upper lobe and was necropsied 4 days later. Animal B2 (Study II) received Ad.CMVlacZ ( $10^{10} \mathrm{pfu}$ ) $\mathrm{ml})$ as described above as well as Ad.CMVCFTR $\left(10^{10} \mathrm{pfu} / \mathrm{ml}\right)$ in the posterior segment of the right upper lobe; this animal has been followed for long-term complications of gene transfer.
The remaining 12 baboons were part of a dose-response trial in which each was instilled with Ad.CMVlacZ in the posterior segment of the left upper lobe and Ad.CBCFTR in the posterior segment of the right upper lobe. The animals were divided into four groups of 3 animals with each group receiving a different concentration of virus in the fluid instilled into the bronchi: Group A, $10^{10} \mathrm{pfu} / \mathrm{ml}$; Group B, $10^{9} \mathrm{pfu} / \mathrm{ml}$; Group C, $10^{8}$ $\mathrm{pfu} / \mathrm{ml}$; and Group D, $10^{7} \mathrm{pfu} / \mathrm{ml}$. Within each group, animals were necropsied 3 and 21 days after instillation and the remaining animal has been followed for long-term complications.

\section{Specimen collection and chest radiographs}

Before virus administration and again on days 4,14 , and 21 post-infection, arterial blood was drawn from the femoral artery for measurement of blood gases (heparin), serum chemistries, blood cell counts (sodium EDTA), viral cultures (heparin), and prothrombin and partial thromboplastin times (sodium citrate). A urethral catheter was inserted into the bladder to obtain urine for routine analysis and viral culture. Blood cell counts, coagulation times, and arterial blood gas analyses, and serum measurements were done by the clinical laboratories of University Hospital, Ann Arbor, MI. Nasopharyngeal secretions and rectal stool samples were collected by cotton swabs for adenoviral cultures. Ventral-dorsal and left lateral recumbent chest radiographs were performed.

TABLE 1. SUMMARY OF EXPERIMENTS

\begin{tabular}{|c|c|c|c|c|c|c|c|}
\hline \multicolumn{4}{|c|}{ Animal } & \multicolumn{3}{|c|}{ Virus } & \multirow[b]{2}{*}{ Analysis } \\
\hline$I . D$. & Species $^{4}$ & Age & $\begin{array}{l}W t \\
(\mathrm{~kg})\end{array}$ & $\begin{array}{c}\text { Conc. } \\
(p f u / m l)\end{array}$ & $\begin{array}{l}\text { Vol. } \\
(m l)\end{array}$ & $\begin{array}{c}\text { Total } \\
\left(p f u \times 10^{\varphi} / \mathrm{kg}\right)\end{array}$ & \\
\hline \multicolumn{8}{|l|}{ Study I } \\
\hline $\mathrm{B} 1^{\mathrm{b}}$ & $\mathrm{PC}$ & 12 years & 32.5 & $10^{10}$ & 20 & 6.1 & Necropsy day 3 \\
\hline Study Il & & & & & & & \\
\hline $\mathrm{B} 2^{\mathrm{b}}$ & PC & 12 years & 32.5 & $10^{10}$ & 20 & 6.1 & Long term \\
\hline \multicolumn{8}{|l|}{$\begin{array}{l}\text { Study III } \\
\text { III-A }\end{array}$} \\
\hline$B 4^{\mathrm{C}}$ & PP & Adolescent & 7.7 & $10^{10}$ & 7 & 10 & Necropsy day 4 \\
\hline$B 6^{\mathrm{C}}$ & PP & Adolescent & 13.6 & $10^{10}$ & 7 & 5.1 & Necropsy day 21 \\
\hline$B 8^{c}$ & PP & Adolescent & 10.4 & $10^{10}$ & 7 & $\begin{array}{c}6.7 \\
\text { Ave }=7.3\end{array}$ & Long term \\
\hline \multicolumn{8}{|l|}{ III-B } \\
\hline $\mathrm{B} 11^{\mathrm{b}}$ & PP & 2.2 years & 6.7 & $10^{9}$ & 7 & 1.0 & Necropsy day 4 \\
\hline $\mathrm{B} 13^{\mathrm{C}}$ & PP & Adolescent & 8.8 & $10^{9}$ & 7 & 0.8 & Necropsy day 21 \\
\hline $\mathrm{B} 15^{\mathrm{c}}$ & $\mathrm{PP}$ & Adolescent & 9.3 & $10^{9}$ & 7 & $\begin{array}{c}0.75 \\
\text { Ave }=0.97\end{array}$ & Long term \\
\hline \multicolumn{8}{|l|}{ III-C } \\
\hline $\mathrm{B} 10^{\mathrm{C}}$ & PP & Adolescent & 6.1 & $10^{8}$ & 7 & 0.1 & Necropsy day 4 \\
\hline $\mathrm{B} 14^{b}$ & PP & 2.4 years & 8.7 & $10^{8}$ & 7 & 0.08 & Necropsy day 21 \\
\hline $\mathrm{B} 16^{\mathrm{c}}$ & $\mathrm{PP}$ & Adolescent & 9.2 & $10^{8}$ & 7 & $\begin{array}{c}0.08 \\
\text { Ave }=0.09\end{array}$ & Long term \\
\hline \multicolumn{8}{|l|}{ III-D } \\
\hline $\mathrm{B} 3^{\mathrm{b}}$ & PP & 4.3 years & 10.4 & $10^{7}$ & 7 & 0.007 & Necropsy day 4 \\
\hline$B 5^{b}$ & $\mathrm{PP}$ & 4.3 years & 12.0 & $10^{7}$ & 7 & 0.006 & Necropsy day 21 \\
\hline $\mathrm{B} 7^{\mathrm{b}}$ & $\mathrm{PP}$ & 5.0 years & 11.4 & $10^{7}$ & 7 & $\begin{array}{c}0.006 \\
\text { Ave }=0.007\end{array}$ & Long term \\
\hline
\end{tabular}

${ }^{a}$ PC, Papio Cynocephalus; PP, Papio papio.

${ }^{\mathrm{h}}$ Bred in captivity.

${ }^{c}$ Caught in the wild. 


\section{Gene construction and administration}

Details for Ad.CBCFTR and Ad.CMVlacZ construction and their intrabronchial administration are provided in the preceding companion article (Engelhardt et al., 1993b).

\section{Bronchoscopy with bronchoalveolar lavage and bronchial brushings}

The animals were tranquilized with intramuscular tiletamine/ zolazepam and maintained in a heavily sedated state by repeated intramuscular doses of the same agents or with intravenous thiamylal $(2.5 \mathrm{mg} / \mathrm{kg})$. For the 2 larger animals, a FB-18X Pentax fiberoptic bronchoscope was inserted through a $9-\mathrm{mm}$ cuffed endotracheal tube; for the 12 smaller animals, a FB-10X Pentax fiberoptic bronchoscope was inserted through a $5.5-\mathrm{mm}$ uncuffed endotracheal tube. Bronchoalveolar lavage was performed by instilling normal saline $(25 \mathrm{ml}$ for the larger animals and $10 \mathrm{ml}$ for the smaller animals) through a wedged bronchoscope as a single bolus. The fluid was immediately aspirated and placed into a tube that was kept on ice. Cells obtained by bronchoalveolar lavage were sedimented onto poly(L-lysine)coated slides by a cytocentrifuge. The air-dried slides were stained with a modified Wright's stain and examined for identification of cell types.

\section{RESULTS}

\section{General response of animals}

The animals tolerated the bronchoscopic instillation of Ad.CBCFTR and Ad.CMVlacZ without complication except that 3 animals (B11, B13, B16) vomited immediately after intratracheal intubation prior to gene infusion. Two of these animals (B11, B13) also vomited when intubated during the follow-up bronchoscopies. In none of these episodes was intratracheal aspiration observed bronchoscopically. During the post-transfection period, the behavior of the animals was normal. They continued to eat normally and their weight changed less than $3 \%$ in the post-transfection period. Rectal temperatures, measured while the animals were sedated for studies, were never elevated.

\section{Hematologic counts}

Blood hemoglobin concentrations remained within normal range in all animals during the 3 weeks following transfection (Fig. 1A). When the animals were analyzed as a single group, white blood cell counts decreased between day 0 and day 4 $(p<0.01$ ), but remained within the normal range (Fig. 1B). The extent of reduction was not directly related to viral dose. After day 4 , the counts increased so that by day 15 they were no different from baseline ( $p>0.1$, analysis of variance). White blood cell differential counts were normal except that at some time during the study, 6 animals (B2, B6, B7, B13, B I5, B 16) had mildly elevated percent monocytes (maximum of $11 \%$ ). Three of these animals (B2, B7, B13) had monocyte elevations on day 0 prior to gene administration. The other 3 animals belong to groups that received $10^{7}, 10^{8}$, an $10^{9} \mathrm{pfu} / \mathrm{ml}$ doses.
Blood platelet counts remained in the normal range on all measurements and did not change during the study (Fig. 1C).

\section{Serum electrolytes, proteins, enzymes, and urinalyses}

Serum concentrations of $\mathrm{Na}^{+}, \mathrm{K}^{+}$, and $\mathrm{Cl}^{-}$were normal and remained unchanged throughout the study. Two animals (B11, B15) had low serum $\mathrm{HCO}_{3}{ }^{-}$levels on day $0(15$ and $17 \mathrm{mEq} /$ liter) prior to gene administration. Arterial blood $\mathrm{pH}$ was also low in these samples (discussed below). During the follow-up period, the $\mathrm{HCO}_{3}{ }^{-}$concentration in these 2 animals increased toward the normal range. Calcium, phosphorous, total protein, and albumin remained normal. Six animals (B6, B8, B11, B14, $\mathrm{B} 15, \mathrm{~B} 16)$ had low levels of proteinuria on one or more urine samples during the study. Several of these occasions were likely due to traumatic catheterizations because gross hematuria was also present in the catheterization specimens but not noted when the animals spontaneously voided later in the day. The proteinuria was not related to viral dose or the number of days

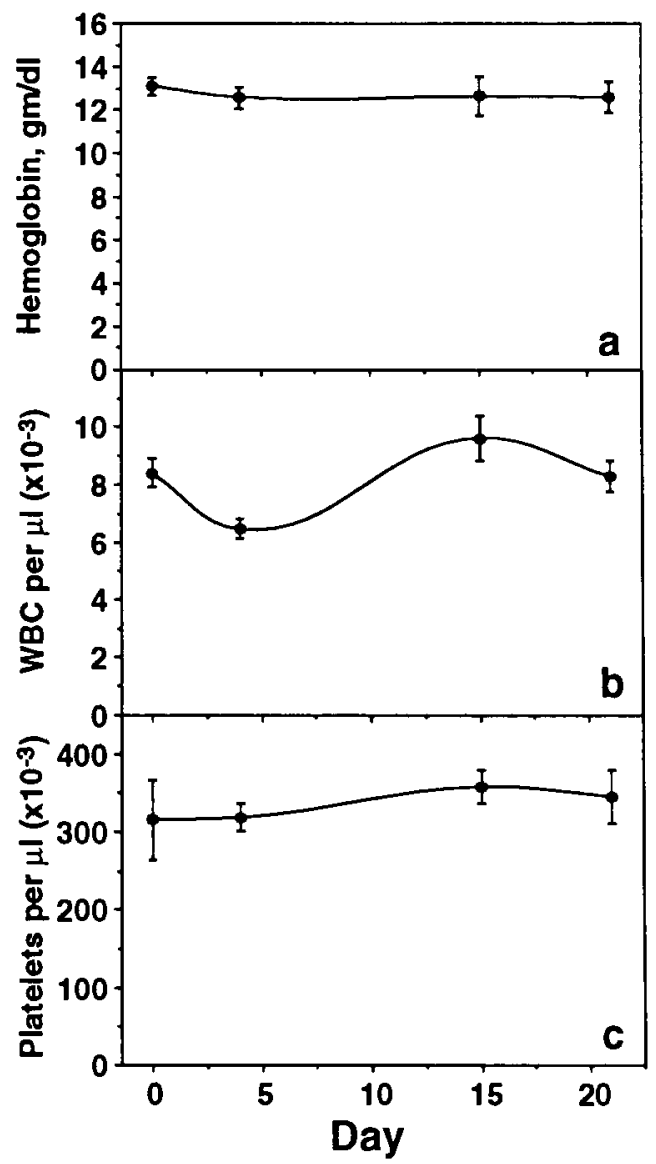

FIG. 1. Effects of gene transfer on hematologic values. Blood was drawn into tubes containing sodium EDTA from the femoral artery immediately prior to intrabronchial gene administration (day 0 ) and again on days 4,15 , and 21 . A. Blood hemoglobin concentrations. B. White blood cell counts. C. Blood platelet counts are expressed as the mean \pm SEM of all animals tested. The values were not directly influenced by the dose of virus administered. 
post-transfection. Serum creatinine and blood urea nitrogen were normal in all animals throughout the study. Liver function tests [aspartate transaminase (AST), alanine transaminase (ALT), lactate dehydrogenase, alkaline phosphatase, and bilirubin] were normal except for one animal (B2) that had mild enzyme elevations at baseline (e.g., AST 56 IU/liter, ALT 85 IU/liter) that remained stable or improved during the study. Prothrombin time and partial thromboplastin time were always normal.

\section{Arterial blood gases}

Arterial blood samples obtained while the animals were sedated prior to gene administration showed a moderately wide range of $\mathrm{PaCO}_{2}$ levels with a mean $\pm \mathrm{SD}$ of $44.8 \pm 4.3 \mathrm{mmHg}$ (range 36.7 to $54.7 \mathrm{mmHg}$ ). The elevated $\mathrm{PaCO}_{2}$ levels are likely due to hypoventilation and atelectasis, which has been previously reported when baboons are sedated (Guenter et al., 1969). The measured levels of $\mathrm{PaCO}_{2}$ remained elevated throughout the study with no changes directly related to viral dose or to the number of days post-transfection.

As mentioned above, arterial blood $\mathrm{pH}$ levels were low in two animals (B11, B15) at baseline prior to gene transfection ( $\mathrm{pH} 7.15$ and 7.28). Acute hypoventilation was not solely responsible for the low $\mathrm{pH}$ in that the $\mathrm{PaCO}_{2}$ levels were no higher in these 2 animals compared with the others. The anion gaps $\left(\mathrm{Na}^{+}-\left[\mathrm{K}^{+}+\mathrm{HCO}_{3}^{-}\right]\right)$in these 2 animals were increased indicating a metabolic acidosis. The unmeasured anions were not identified, but were unlikely to be ketone bodies because none were detected in the urine. During the study, the low $\mathrm{pH}$ levels improved in these animals; the $\mathrm{pH}$ of one animals (B11) increased from 7.15 to 7.32 by necropsy on day 4 , and of the other animal ( $\mathrm{B} 15$ ) from 7.28 to 7.39 by day 15 .

Baseline $\mathrm{PaO}_{2}$ was $78.1 \pm 11.0 \mathrm{mmHg}$ (mean $\pm \mathrm{SD}$, range $54.0-98.0 \mathrm{mmHg}$ ). To compensate for changes in $\mathrm{PaO}_{2}$ caused by changes in ventilation, the $\mathrm{PaO}_{2}$ data were analyzed using the calculated alveolar to arterial oxygen gradient $\left(\mathrm{P}(\mathrm{A}-\mathrm{a}) \mathrm{O}_{2}\right)$. The mean $\mathrm{P}(\mathrm{A}-\mathrm{a}) \mathrm{O}_{2}$ on day 0 prior to gene administration was $12.5 \pm 7.0$ (SD) with a range of $0.0-26.6$. Because the wide range of baseline $\mathrm{P}(\mathrm{A}-\mathrm{a}) \mathrm{O}_{2}$ levels might obscure a treatmentinduced change in gas exchange, the data were analyzed using the change in $\mathrm{P}(\mathrm{A}-\mathrm{a}) \mathrm{O}_{2}$ from the day 0 level $\left(\Delta \mathrm{P}(\mathrm{A}-\mathrm{a}) \mathrm{O}_{2}\right)$. When analyzed in this fashion, no statistically significant effect on $\Delta \mathrm{P}(\mathrm{A}-\mathrm{a}) \mathrm{O}_{2}$ was found for viral dose or from the time interval post-transfection. However, inspection of the relationship between $\Delta \mathrm{P}(\mathrm{A}-\mathrm{a}) \mathrm{O}_{2}$ and the number of days post-transfection did suggest a trend (Fig. 2). The higher dose animals (Groups $A$ and $B$ ) were more likely to have an increase (worsening) in $\mathrm{P}(\mathrm{A}-\mathrm{a}) \mathrm{O}_{2}$ while the lower dose animals (Groups $\mathrm{C}$ and $\mathrm{D}$ ) had $\mathrm{P}(\mathrm{A}-\mathrm{a}) \mathrm{O}_{2}$ levels more equally distributed between increased and decreased levels.

\section{Chest radiographs}

Supine ventral-dorsal chest radiographs were taken in all animals. Detection of infiltrates was complicated by transient atelectasis that apparently occurred when the animals were sedated (Guenter et al., 1969). We noted that the side of the chest on which atelectasis occurred was often the side on which the animal was laying prior to taking the $X$-ray. Repositioning the

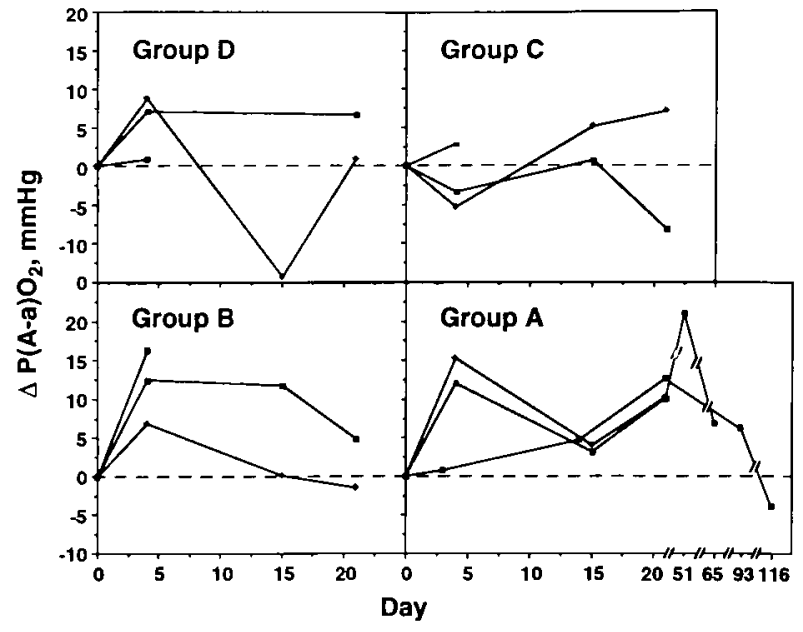

FIG. 2. Effects of gene transfer on the difference between alveolar and arterial oxygen tensions. Blood was drawn from the femoral artery immediately prior to intrabronchial gene administration (day 0 ) and again on days 4,15 , and 21 in animals that received $10^{7}$ (Group D), $10^{8}$ (Group C), $10^{9}$ (Group B), and $10^{10}$ (Group A) pfu/ml of virus. Additional samples were obtained on later days from the long-term animals receiving $10^{10} \mathrm{pfu} / \mathrm{ml}$ viral dose. The alveolar air equation was used to calculate the alveolar to arterial oxygen tension difference $\left(\mathrm{P}(\mathrm{A}-\mathrm{a}) \mathrm{O}_{2}\right)$ using arterial $\mathrm{PO}_{2}$ and $\mathrm{PCO}_{2}$ measurements and assuming the respiratory exchange ratio to be 0.8 . The change in $\mathrm{P}(\mathrm{A}-\mathrm{a}) \mathrm{O}_{2}$ in $\mathrm{mmHg}$ from the level on day $0\left(\Delta \mathrm{P}(\mathrm{A}-\mathrm{a}) \mathrm{O}_{2}\right)$ is displayed for groups of animals receiving each dose of virus.

animal into the opposite decubitus position for a minute and then rotating him to the supine position would expand the atelectatic area. After compensating for these artifacts, it became possible to analyze the chest radiographs for appearance of abnormalities. No infiltrates appeared in any animal receiving $10^{7}, 10^{8}$, or $10^{9} \mathrm{pfu} / \mathrm{ml}$ doses. New alveolar infiltrates occurred in 3 of the 4 animals receiving $10^{10} \mathrm{pfu} / \mathrm{ml}$ dose (Fig. 3). To display the location and severity of the infiltrate, a grading system was used. The upper, middle, and lower lung fields of each lung were separately graded for alveolar infiltrates: Mild, minimally detectable infiltrate; moderate, infiltrate occupying $1 / 4$ of lung field; severe, infiltrate occupying $1 / 2$ or more of lung field. The infiltrates generally first appeared on days 15 and 21 post-transfection (Fig. 4). In one of the long-term animals (B2), streaky infiltrates were present in both upper lobes on day 0 prior to transfection. The infiltrates worsened on day 21 , but completely resolved by the radiograph taken on day 73 . The infiltrate that appeared in the other long-term $10^{10} \mathrm{pfu} / \mathrm{ml}$ animal completely resolved by the X-ray performed on day 39 .

\section{Bronchoscopic results}

Bronchoalveolar lavage was performed on long-term animals three times during the study. On day 0 , the right middle lobe was lavaged, and on days 4 and 21 the posterior segments of right and left upper lobes were lavaged. Approximately $50 \%$ of the instilled volume was recovered with no variation depending on viral dose or time following gene administration. The cell concentration of the bronchoalveolar lavage fluid obtained from 


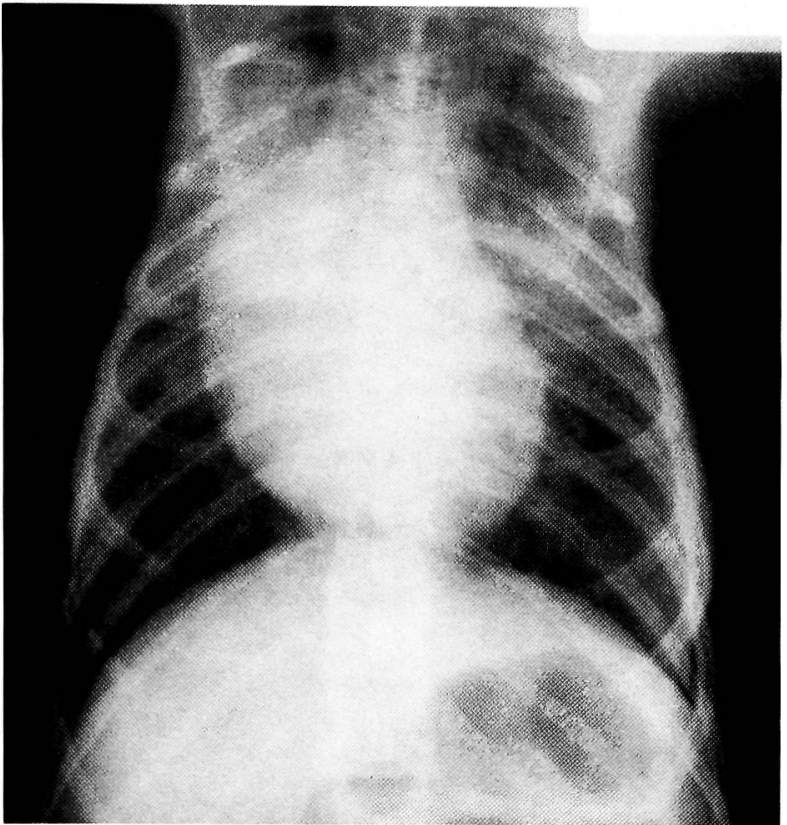

FIG. 3. Chest radiograph taken on day 15 of an animal that received $10^{10} \mathrm{pfu} / \mathrm{ml}$ viral dose. This supine ventral-dorsal chest radiograph has the greatest degree of abnormality seen in any animal during the study. It shows alveolar infiltrates occupying most of the right upper lung field, less than half of the left upper lung field, and barely present in the right lower lung field.

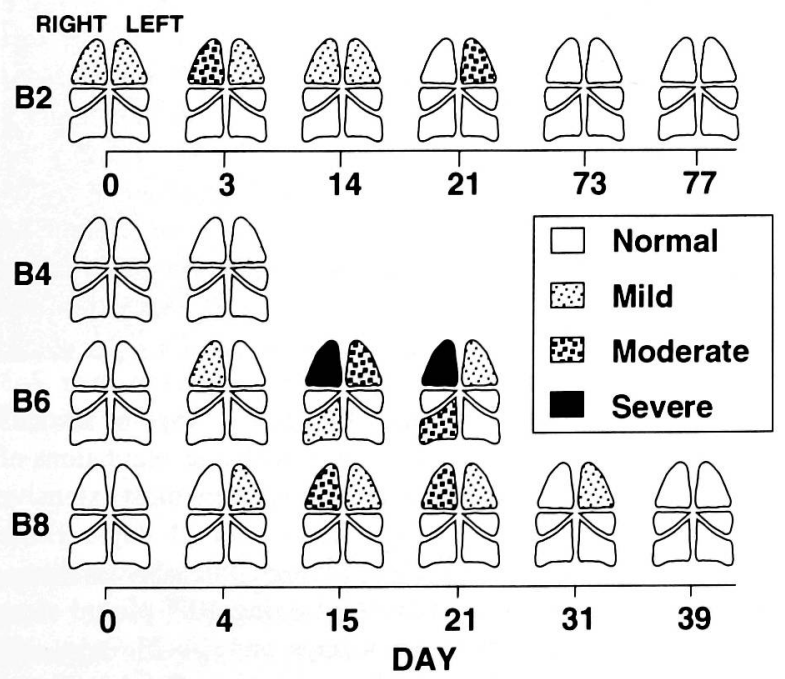

FIG. 4. Location and extent of chest radiographic abnormalities detected before and after gene administration. The extent of alveolar infiltrates in each of six fields is depicted using a grading system defined in the text. Because all animals receiving $10^{7}, 10^{8}$, and $10^{9} \mathrm{pfu} / \mathrm{ml}$ doses had normal chest radiographs throughout the study, only data from the $10^{10} \mathrm{pfu} / \mathrm{ml}$ dose animals are displayed. the right middle lobe on the day of gene instillation was $2.32 \times 10^{6} \pm 1.08 \times 10^{6}(\mathrm{SD})$ cells $/ \mathrm{ml}$. Cell numbers measured in lavage fluid obtained during follow-up bronchoscopies showed no trend relative to day post-transfection, dose, or side on which the lavage was performed. Analysis of the cell differential counts was complicated by the finding that on day 0,1 animal (B2) had markedly elevated percent neutrophils and another (B16) had elevated percent lymphocytes. Even including these suspected outliers, the percent neutrophils changed significantly over time $(p<0.03)$ with a peak at 4 days and a reduction back to baseline at day 21 (Fig. 5A). This pattern occurred independent of the dose of virus administered. The percent lymphocytes also changed significantly over time $(p<0.04)$ with an increase occurring between day 4 and day 21 (Fig. 5B). This increase was not influenced by the dose of virus administered and was independent of the side lavaged. Sporadic increases were seen in percent eosinophils; the eosinophils were usually present in only one of the two segments lavaged (not consistently the left or right side) and then only for a single point in time.

\section{Necropsy}

Grossly, the lungs of all animals appeared normal with two exceptions. The animal (B6) that was sacrificed 21 days after receiving $10^{10} \mathrm{pfu} / \mathrm{ml}$ virus had hemorrhagic and grayish patches located predominantly over the dorsal surfaces of the right upper, left upper, and right lower lobes. Also one animal (B11) had punctate green-black colored 1-mm spots scattered over the entire surface of both lungs (discussed below).

To a varying degree and correlating with viral dose, the animals developed a lymphocytic perivascular alveolar infiltrate (Fig. 6). At its mildest, small lymphocytic accumulations were seen surrounding small to medium-sized vessels within lung parenchyma. Increased numbers of alveolar macrophages were also present. With increasing severity of the abnormality, the lymphocytic infiltrate extended beyond the immediate perivascular area and into the alveolar interstitial spaces. Intraalveolar lymphocytes occasionally accompanied the increased number of macrophages. In lung regions having a higher intensity of penumonitis, the alveolar tissue was densely infiltrated with mononuclear cells and at its worse, intra-alveolar edema could be seen. Figure 7 depicts the location and severity of the penumonitis in the 8 animals on which necropsies were performed. Inflammation was absent or very mild in the lungs of all animals sacrificed on day 4 and in the lungs of animals receiving $10^{7}$ and $10^{8} \mathrm{pfu} / \mathrm{ml}$ doses at day 21 . Moderate to severe inflammation was seen in several areas of lung in the animals receiving $10^{10} \mathrm{pfu} / \mathrm{ml}$ and in one area of lung in the animal receiving $10^{9} \mathrm{pfu} / \mathrm{ml}$ dose. The inflammation was more likely present in regions of lung where virus was directly infused. However, it was also occasionally present outside these areas. There seemed to be little if any difference in the degree of inflammation between the side receiving Ad.CMVlacZ and the side receiving Ad.CBCFTR. In scattered areas, eosinophils and rarely neutrophils could be seen. These cells were never the dominant type of inflammatory cell.

The majority of the inflammation was located within the distal lung parenchyma. There was no evidence of vessel wall necrosis, although the lymphocytic infiltrate seemed to arise 

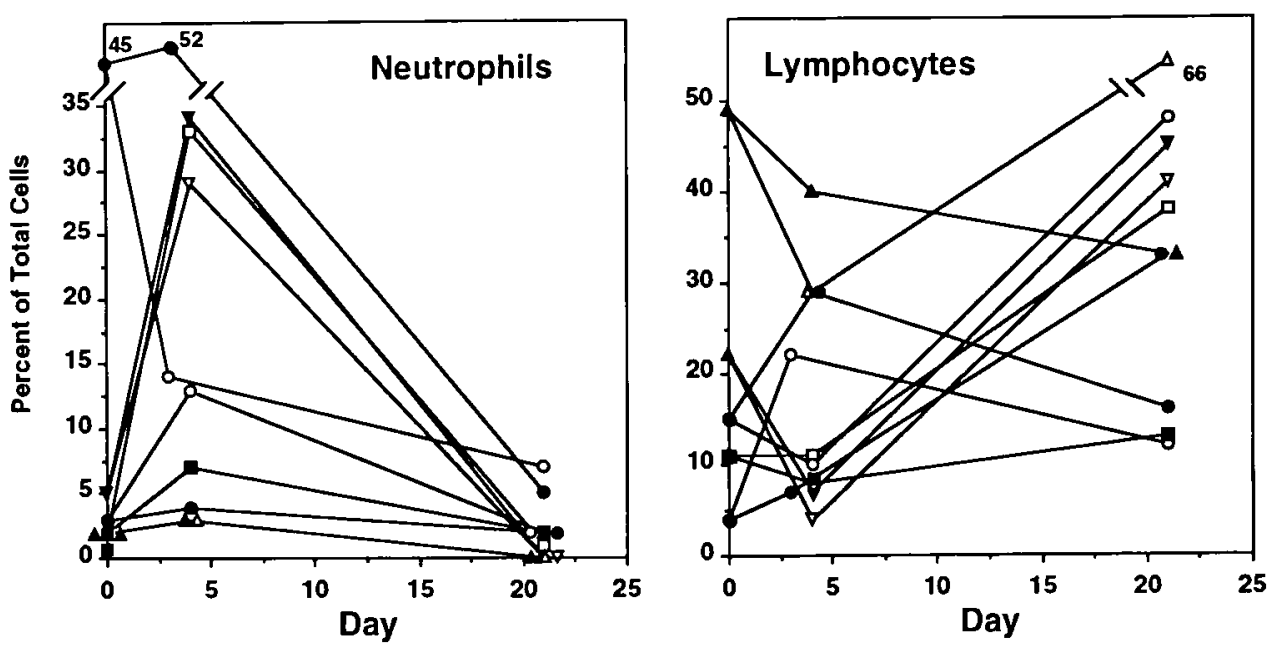

FIG. 5. Bronchoalveolar lavage fluid differential cell counts before and after gene administration. Immediately prior to gene transfer, the right middle lobe of each long-term animal was lavaged. On days 4 and 21, the posterior segment of the right upper lobe (solid symbols) and left upper lobes (open symbols) of the long-term animals were separately lavaged Cytocentrifuge preparations were made and the cells stained with a modified Wright's stain. Data from animals receiving $10^{7}(\mathbf{E}, \square), I 0^{8}(\Lambda, \Delta)$, $10^{9}(\nabla, \nabla)$, and $10^{10}(\bullet, 0) \mathrm{pfu} / \mathrm{ml}$ are displayed separately.

around small vessels. The airways were relatively spared by the inflammation. Uncommonly, the well-demarcated bronchialassociated lymphoid aggregates would spread to infiltrate bronchial wall. In almost all instances, the epithelium remained intact with preservation of its pseudocolumnar pattern with abundant ciliated cells.

In 3 animals (B11, B13, B 14), all captured in the wild, micronodules consisting of accumulations of macrophages were found scattered diffusely throughout the lung parenchyma. The macrophages contained a dark greenish-black pigment, part of which was refractile, suggesting the presence of silicates. In one of the 3 animals (B14), a small number of lymphocytes surrounded the macrophage aggregates. The source and precise identity of the material are unknown.

\section{Nonpulmonary organs}

Grossly and microscopically, the nonpulmonary organs contained no abnormalities referable to gene treatment. In one of the wild-caught animals (B13), parasitic cysts were seen in skeletal muscle, in bone marrow, and in two areas within the liver.

\section{DISCUSSION}

The major adverse effect associated with intrabronchial instillation of the adenovirus-based vectors was pulmonary alveolar inflammation. Examination of blood, urine, and tissue obtained at necropsy failed to show any abnormalities in nonrespiratory organs attributable to transfection. The severity and location of the inflammatory infiltrate depended upon the concentration of virus to which the lung tissue was exposed. Animals receiving $10^{7}$ and $10^{8} \mathrm{pfu} / \mathrm{ml}$ adenovirus showed little if any inflammation. At $10^{9}$ and much more prominently at $10^{10}$ $\mathrm{pfu} / \mathrm{ml}$, a mononuclear cell infiltrate was seen within regions of the alveolar space. This correlated with the level of transgene expression, with $10^{10} \mathrm{pfu} / \mathrm{ml}$ yielding more gene product than $10^{9} \mathrm{pfu} / \mathrm{ml}$. In general, the regions of the lung where virus was -directly infused were most likely to show evidence of inflammation on chest radiographs and lung histology. However, inflammation was not restricted solely to these areas. The occurrence of inflammation outside the targeted regions is likely due to spill-over during virus infusion. Positive staining with X-gal was seen in a limited region of the left lower lobe in an adult animal receiving $10^{10} \mathrm{pfu} / \mathrm{ml}$ into the posterior segment of the left upper lobe (Engelhardt et al., 1993b). In the smaller animals, occlusions of the bronchus to the target segment appeared even less effective than using a balloon catheter in the larger 2 animals. Additional evidence of spill-over was evident by the presence of positively stained alveolar walls in a limited region of the X-gal-stained histologic sections from the left middle lobe of the animal (B4) necropsied 4 days after administration of $10^{10} \mathrm{pfu} / \mathrm{ml} \mathrm{Ad.CMVlacZ}$ into the posterior segment of the left upper lobe.

The inflammatory reaction appeared to develop over 2-3 weeks following gene administration. In the lungs of animals necropsied at 4 days, only mild, perivascular accumulations of lymphocytes were seen. The abnormalities were most extensive in animals receiving $10^{10} \mathrm{pfu} / \mathrm{ml}$ virus after 21 days. These finding were paralleled by chest radiographic abnormalities, which were seen only in animals receiving $10^{10} \mathrm{pfu} / \mathrm{ml}$ virus and which worsened between 4 days and 14-21 days. No necropsies were done past 21 days, therefore the duration of inflammation is not precisely known. However, the abnormalities that were seen on chest radiographs resolved completely on follow-up examination.

The noninvasive or minimally invasive techniques that were used to detect pulmonary inflammation turned out to be insensitive. The animals' physical appearance and behavior appeared 

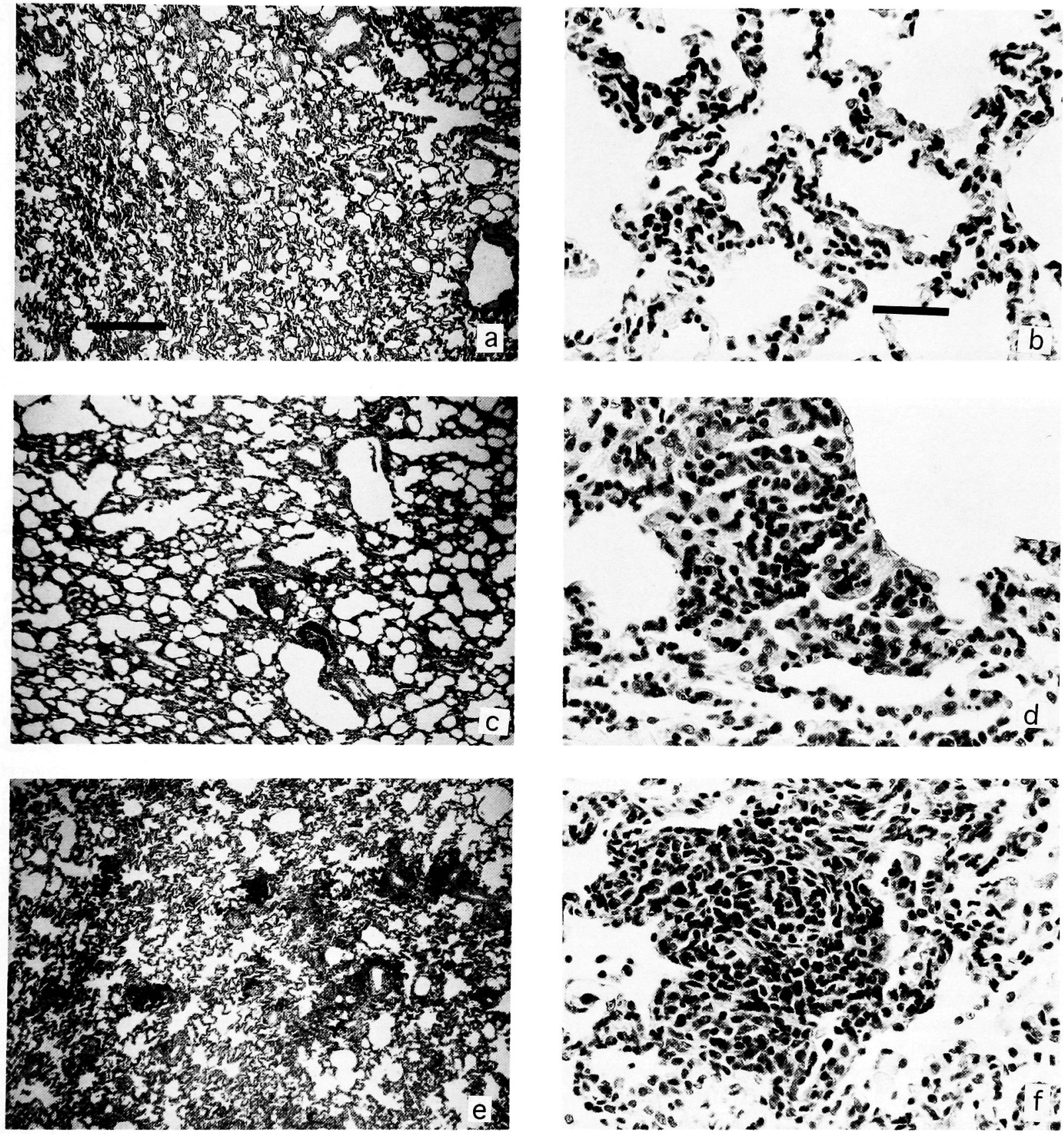

FIG. 6. (Figure and legend continued on page 778.)

normal throughout the study. Blood tests likewise did not accurately reflect the presence of lung inflammation. The failure of blood gas analysis to provide an indicator of lung impairment might have been due to confounding effects of hypoventilation and atelectasis that occurred during the period of sedation that was necessary to safely study the animals (Guenter et al., 1969). The types of cells found in bronchoalveolar lavage did change following gene administration; however, the changes were as likely to occur in animals with high-intensity alveolar inflammation as animals having minimal, if any inflammation.
Also, the changes were not restricted to the segment of lung receiving Ad.CMVlacZ or Ad.CBCFTR.

The precise cause of the inflammatory response cannot be discerned from the available data. It is unlikely that cell lysis from viral replication initiated the injury because in general, no late viral proteins were seen and no recombinant or wild-type viruses were detected by culture, except for a single positive bronchoalveolar lavage specimen obtained at 4 days. A more likely cause of the pulmonary inflammation is a response to viral antigens. The time course and perivascular location of the 

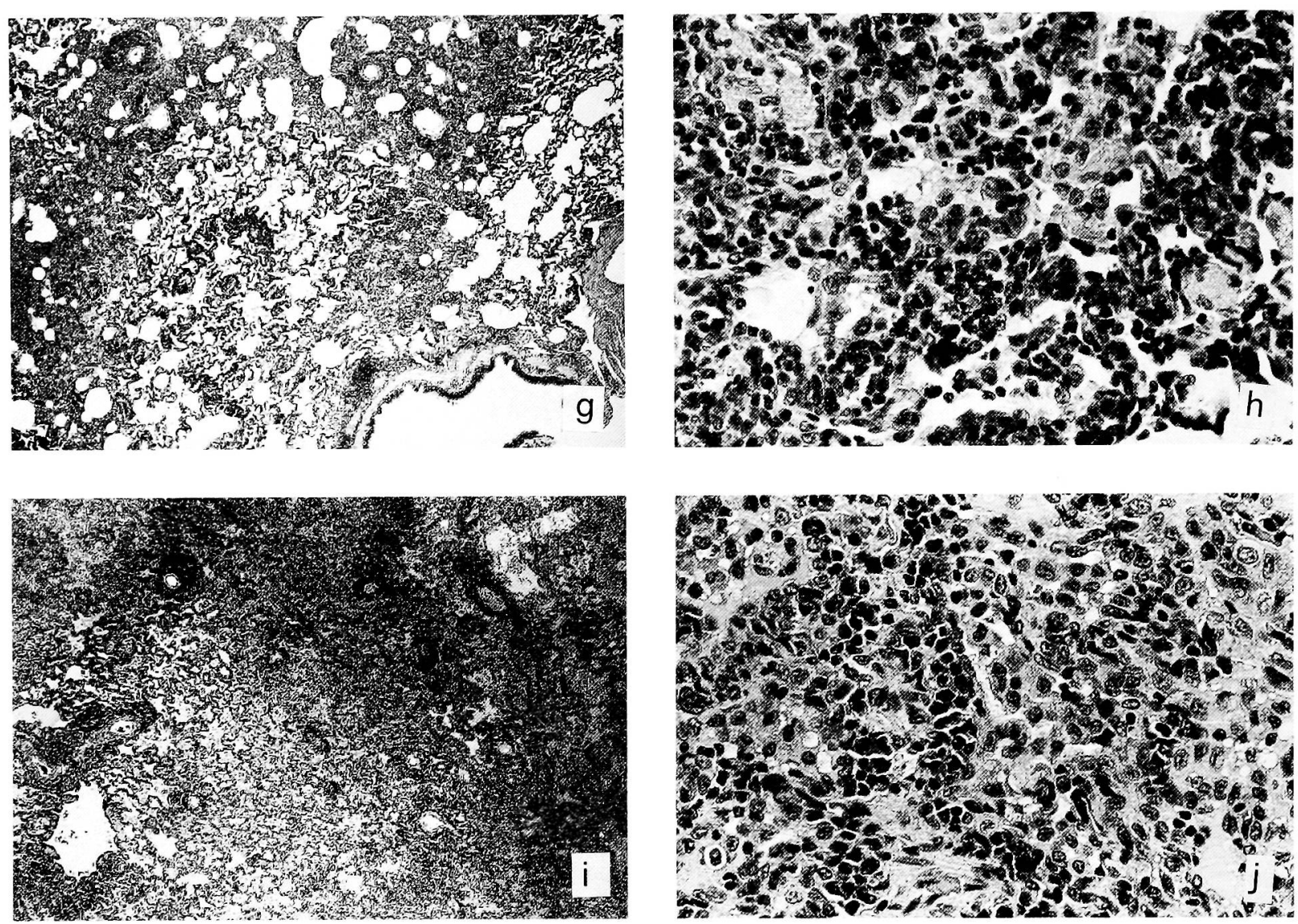

FIG. 6. Representative histopathology depicting differing intensities of pneumonitis that occurred in the lungs of animals following gene administration. Displayed are photomicrographs of hematoxylin and eosin-stained lung sections that represent different levels of inflammation. The panels showing hematoxylin and eosin-stained lung sections (right upper lobes) are arranged as examples of the different grades of inflammation as defined in the text: Normal (panels a and b, B3), 1+ (panels c and d, B 10), $2+$ (panels e and f, B4), 3+ (panels g and h, B6), and 4+ (panels i and j, B6). The bar in panel a represents $500 \mu \mathrm{m}$ and is also applicable to panels c, e, g, and i; the bar in panel b represents $50 \mu \mathrm{m}$ and is also applicable for panels $\mathrm{d}, \mathrm{f}, \mathrm{h}$, and $\mathrm{j}$.

lymphocytic infiltrates are compatible with a naive response to foreign antigens. The immune response was likely initiated by virus that was instilled on day 0 . This is supported by ELISA and Western blot analysis of sera for antibodies to adenoviral proteins. None of the animals had preexisting antibodies; however, a significant antibody response to adenoviral proteins was detected in animals receiving the highest doses of virus (Kozarsky and Wilson, unpublished data). It is not possible to determine if this challenge was augmented or prolonged by viral antigens synthesized de novo following transfection. Immunofluorescence studies performed on necropsy tissue at day 4 showed limited but detectable expression of nonstructural viral proteins

The occurrence of an inflammatory response within the alveolar space was unlikely to have been heavily influenced by the volume of virus that was infused into the targeted segments of lung. Alveolar transgene expression and inflammation were seen not only within the posterior segments of the upper lobes, but in rare instances in regions of lung that were likely exposed as part of spill-over during virus administration. These secondarily exposed regions almost certainly were subjected to much lower volumes of virus. Despite these lower volumes, alveolar expression and inflammation occurred.

The physiologic consequences of the inflammatory response are likely to be significant. Animals receiving the higher doses of virus had regions of lung that were inflamed enough at 21 days that these regions were unlikely to be able to participate in gas exchange. Alveoli within these areas of lung were filled with inflammatory cells and fluid. In regions showing milder levels of inflammation, the majority of the alveoli remained air filled and might have been able to contribute to gas exchange. It is unknown whether the injured areas of lung were able to recover and function again as gas exchange units. The inflammatory reaction appeared to be at least partially reversible. The infiltrates seen on chest radiographs in the animals receiving $10^{10} \mathrm{pfu} / \mathrm{ml}$ virus resolved on follow-up films. However, it appears that the chest radiographs detected only the most severely inflamed regions of lung. Mild to moderate areas of inflammation detected histologically were not seen on the chest radiographs obtained immediately prior to sacrifice and necropsy.

The appearance of inflammation at concentrations of virus 


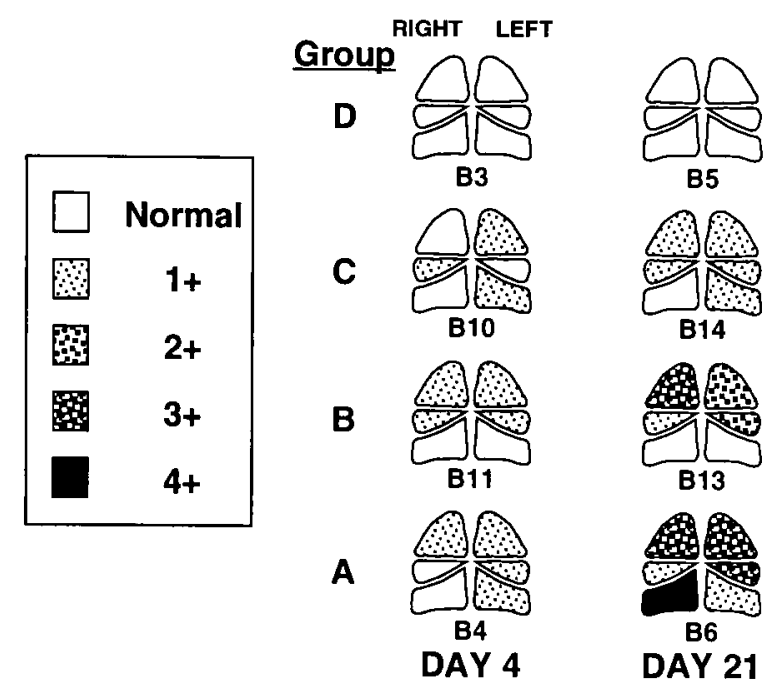

FIG. 7. Location and extent of pneumonitis in the lungs of animals following gene administration. Each field (upper, middle, and lower) of the right and left lung is schematically represented for animals that received $10^{7}$ (Group D), $10^{8}$ (Group C), $10^{9}$ (Group B), and $10^{10}$ (Group A) pfu/ml viral doses and were necropsied on days 4 or 21 . The degree of inflammation depicted for each field represents an averaging of the level of inflammation seen on multiple (2-4) sections from each lobe.

necessary to induce transgene expression in the baboons causes concern. If similar degrees of inflammation occur in humans, it is unlikely that these vectors can be used without further modifications. However, there are cogent reasons to believe that the response in humans may not closely mimic the observations in baboons. The recombinant viruses used in these experiments are based on serotype 5 adenovirus which infects humans. It is not known whether this serotype naturally infects baboons or what type of disease, if any, it causes (Dick and Dick, I974; Rodriguez et al., 1977). The concentration of virus needed to transfect in vivo and express CFTR in human airways may differ considerably from that needed to transfect baboon cells. Similarly, the relationship between the dose needed for transgene expression may be lower than that which might induce inflammation in the human. The types of epithelial cells that will preferentially transfected following administration of adenoviral vectors to human airways may not be the same as was observed in the baboons. The clinical syndrome and pathological changes that are seen following adenovirus infection in humans shows that airway epithelial cells are a primary target of infection (Jackson and Muldoon, 1973; Schaefer, 1983; Straus, 1984; Zahradnik, 1987). Even in severe cases of human adenoviral pneumonia where alveolar epithelial injury is prominent, the airway epithelial cells are always profoundly injured as well. This dominance of airway epithelial involvement in humans differs from the pattern we observed in the baboons. Even at the highest doses of virus where we found diffuse alveolar inflammation, the airways were almost completely spared. Only rare areas of lymphocytic infiltration of airway epithelium were seen. This predilection for alveolar inflammation in the baboon parallels the predominant site of transgene expression in the baboon where the majority of transfected cells were located within the alveolar compartment with few expressing cells found in the airway epithelium.

Another difference between the baboon experiments and human trials may be the immune status of the recipient. The endemic nature of serotype 5 causes the majority of humans to have been exposed to the virus by the time they reach adulthood. Analysis of sera by Western blot and ELISA indicated that the baboons did not have preexisting immunity to human adenovirus. Indeed, the time course with which the baboons developed alveolitis suggests that they were immunologically naive. The peak level of inflammation was observed at 2-3 weeks after virus administration, which is longer than what would be expected for an anamnestic response. We have not rechallenged the baboons with adenovirus, so we do not know if the kinetics and intensity of inflammation would differ in a previously sensitized animal.

In summary, we found that use of adenoviral vectors to transfect CFTR and lacZ genes into baboon lungs was associated with development of alveolar inflammation. The appearance of this inflammatory response emphasizes the need to carefully monitor for similar adverse effects during the early trials of CF gene therapy in humans.

\section{ACKNOWLEDGMENTS}

We would like to thank Dr. Barry H. Gross for assistance in interpreting chest radiographs, Dr. Clarence Chrisp for analyzing pathology specimens, Dr. John F. Wilson for performing necropsies, Mr. John L. Decoster and Ms. Karen A. CArter for assistance in handling the baboons, and Ms. Debra Jurmu for help in preparing the manuscript.

\section{REFERENCES}

DICK, E.C., and DICK, C.R. (1974). Natural and experimental infections of nonhuman primates with respiratory viruses. Lab. Animal Sci. 24, 177-181.

ENGELHARDT, J.E., YANG, Y., STRATFORD-PERRICAUDET, L.D., ALLEN, E.D., KOZARSKY, K., PERRICAUDET, M., YANKASKAS, J.R., and WILSON, J.M. (1993a). Direct gene transfer of human CFTR into human bronchial epithelial of xenografts with E1-deleted adenoviruses. Nature Gene. 4, 27-34.

ENGELHARDT, J.F., SIMON, R.H., YANG, Y., ZEPEDA, M., WEBER-PENDLETON, S., DORANZ, B., GROSSMAN, M., and WILSON, J.M. (1993b). Adenovirus-mediated transfer of the CFTR gene to lung of nonhuman primates: Biological efficacy study. Hum. Gene Ther. 4, 759-769.

GUENTER, C.A., MCCAFFREE, D.R., DAVIS, L.J., and SMITH, V.S. (1969). Pulmonary function and hemodynamic studies in the normal, lightly anesthetized baboon. In Neurology Physiology, and Infectious Diseases, Proceedings of the Second International Congress of Primatology Atlanta, GA 1968. H.O. Hofer, ed. (S. Karger, New York) pp. 79.

JACKSON, G.G., and MULDOON, R.L. (1973). Viruses causing common respiratory infection in Man. IV. Reoviruses and adenoviruses. J. Infect. Dis. 126, 811-866.

RODRIGUEZ, A.R., KALTER, S.S., HEBERLING, R.L., HELMKE, R.J., and GUAJARDO, J.E. (1977). Viral infections of the captive kenya baboon (Papio cynocephalus): A five-year epidemiologic study of an outdoor colony. Lab. Animal Sci. 27, 356-371. 
ROSENFELD, M.A., SIEGFRIED, W., YOSHIMURA, K. YONEYAMA, K., FUKAYAMA, M., STIER, L.E., PAAKKO, P.K., GILARDI, P., STRATFORD, P.L., PERRICAUDET, J., JALLAT, S., PAVIRANI, A., LECOCQ, J.P., and CRYSTAL, R.G. (1991). Adenovirus-mediated transfer of a recombinant alpha 1-antitrypsin gene to the lung epithelium in vivo [see comments] Science. 252, 431-434.

ROSENFELD, M.A., YOSHIMURA, K., TRAPNELL, B.C. YONEYAMA, K., ROSENTHAL, E.R., DALEMANS, W. FUKAYAMA, M., BARGON, J., STIER, L.E., STRATFORDPERRICAUDET, L., PERRICAUDET, J., GUGGINO, W.B., LECOCQ, J.P., and CRYSTAL, R.G. (1992). In vivo transfer of the human cystic fibrosis transmembrane conductance regulator gene to the airway epithelium. Cell 68, 143-155.

SCHAEFER, H.E. (1983). Inflammatory disease of the human lung of definite or presumed viral origin. Cytologic and histologic topics. Curr. Top. Pathol. 73, 153-205.

STRAUS, S.E. (1984). Adenovirus infections in humans. In The Ade- noviruses. H.S. Ginsberg, ed. (Plenum Press, New York) pp. 451495.

ZAHRADNIK, J.M. (1987). Adenovirus pneumonia. Sem. Respir. Dis. 2, 104-11I.

Address reprint requests to: Dr. James $M$. Wilson Institute for Human Gene Therapy University of Pennsylvania Medical Center 3601 Spruce Street

Room 204, Wistar Institute Philadelphia, PA 19104-4268

Received for publication July 23, 1993; accepted after revision August 12, 1993. 
This article has been cited by:

1. Y. Yuan, J. Tan, Y. Wang, C. Qian, M. Zhang. 2009. Chitosan nanoparticles as non-viral gene delivery vehicles based on atomic force microscopy study. Acta Biochimica et Biophysica Sinica 41:6, 515-526. [CrossRef]

2. Rukkumani Rajagopalan, Jennifer Xavier, Nandini Rangaraj, Nalam Madhusudhana Rao, Vijaya Gopal. 2007. Recombinant fusion proteins TAT-Mu, Mu and $\mathrm{Mu}-\mathrm{Mu}$ mediate efficient non-viral gene delivery. The Journal of Gene Medicine 9:4, 275-286. [CrossRef]

3. Terence R Flotte, Philip Ng, Doug E Dylla, Paul B McCray, Guoshun Wang, Jay K Kolls, Jim Hu. 2007. Viral Vector-mediated and Cell-based Therapies for Treatment of Cystic Fibrosis. Molecular Therapy 15:2, 229-241. [CrossRef]

4. Pamela L Zeitlin. 2003. Emerging drug treatments for cystic fibrosis. Expert Opinion on Emerging Drugs 8:2, 523-535. [CrossRef]

5. Hayan Dayoub , Randall J. Dumont, Jin Zhong Li , Aaron S. Dumont, Gerald R. Hankins, David F. Kallmes , Gregory A. Helm . 2003. Human Mesenchymal Stem Cells Transduced with Recombinant Bone Morphogenetic Protein-9 Adenovirus Promote Osteogenesis in RodentsHuman Mesenchymal Stem Cells Transduced with Recombinant Bone Morphogenetic Protein-9 Adenovirus Promote Osteogenesis in Rodents. Tissue Engineering 9:2, 347-356. [Abstract] [PDF] [PDF Plus]

6. Frank Martiniuk, Agnes Chen, Adra Mack, Vincent Donnabella, Alfred Slonim, Linda Bulone, Eleni Arvanitopoulos , Nina Raben, Paul Plotz, William N. Rom . 2002. Helios Gene Gun Particle Delivery for Therapy of Acid Maltase DeficiencyHelios Gene Gun Particle Delivery for Therapy of Acid Maltase Deficiency. DNA and Cell Biology 21:10, 717-725. [Abstract] [PDF] [PDF Plus]

7. Hong Du, Martin Heur, David P. Witte, Detlev Ameis, Gregory A. Grabowski . 2002. Lysosomal Acid Lipase Deficiency: Correction of Lipid Storage by Adenovirus-Mediated Gene Transfer in MiceLysosomal Acid Lipase Deficiency: Correction of Lipid Storage by Adenovirus-Mediated Gene Transfer in Mice. Human Gene Therapy 13:11, 1361-1372. [Abstract] [PDF] [PDF Plus]

8. John Nemunaitis, John O'Brien. 2002. Head and neck cancer: Gene therapy approaches. Part 1: Adenoviral vectors. Expert Opinion on Biological Therapy 2:2, 177-185. [CrossRef]

9. Chang-Xin Shi , Mary Hitt, Philip Ng, Frank L. Graham . 2002. Superior Tissue-Specific Expression from Tyrosinase and Prostate-Specific Antigen Promoters/Enhancers in Helper-Dependent Compared with First-Generation Adenoviral VectorsSuperior Tissue-Specific Expression from Tyrosinase and Prostate-Specific Antigen Promoters/Enhancers in Helper-Dependent Compared with First-Generation Adenoviral Vectors. Human Gene Therapy 13:2, 211-224. [Abstract] [PDF] [PDF Plus]

10. James N. Higginbotham, Prem Seth , R. Michael Blaese, W. Jay Ramsey . 2002. The Release of Inflammatory Cytokines from Human Peripheral Blood Mononuclear Cells In Vitro Following Exposure to Adenovirus Variants and CapsidThe Release of Inflammatory Cytokines from Human Peripheral Blood Mononuclear Cells In Vitro Following Exposure to Adenovirus Variants and Capsid. Human Gene Therapy 13:1, 129-141. [Abstract] [PDF] [PDF Plus]

11. Ronald G. Crystal , Ben-Gary Harvey, Juan P. Wisnivesky, Kelley A. O'Donoghue, Karen W. Chu , Jaman Maroni , Jolene C. Muscat, Allison L. Pippo, Connie E. Wright, Robert J. Kaner, Philip L. Leopold, Paul D. Kessler, Henrik S. Rasmussen, Todd K. Rosengart, Charleen Hollmann . 2002. Analysis of Risk Factors for Local Delivery of Low- and Intermediate-Dose Adenovirus Gene Transfer Vectors to Individuals with a Spectrum of Comorbid ConditionsAnalysis of Risk Factors for Local Delivery of Low- and Intermediate-Dose Adenovirus Gene Transfer Vectors to Individuals with a Spectrum of Comorbid Conditions. Human Gene Therapy 13:1, 65-100. [Abstract] [PDF] [PDF Plus]

12. YUZO KODAMA, YASUHIRO SETOGUCHI, YOSHINOSUKE FUKUCHI. 2002. Infection of replication-deficient adenoviral vector enhances interleukin-8 production in small airway epithelial cells more than in large airway epithelial cells. Respirology 6:4, 271-279. [CrossRef]

13. Melanie Olive , Laurence C. Eisenlohr, Phyllis Flomenberg . 2001. Quantitative Analysis of Adenovirus-Specific CD4+ T-Cell Responses from Healthy AdultsQuantitative Analysis of Adenovirus-Specific CD4+ T-Cell Responses from Healthy Adults. Viral Immunology 14:4, 403-413. [Abstract] [PDF] [PDF Plus] 
14. Teresa BorrDs, B'Ann T. Gabelt, Gordon K. Klintworth, John C. Peterson, Paul L. Kaufman. 2001. Non-invasive observation of repeated adenoviral GFP gene delivery to the anterior segment of the monkey eyein vivo. The Journal of Gene Medicine 3:5, 437-449. [CrossRef]

15. Timothy M Crombleholme. 2000. Adenoviral-mediated gene transfer in wound healing. Wound Repair and Regeneration 8:6, 460-472. [CrossRef]

16. Kenneth L. Brigham, Kirk B. Lane, Barbara Meyrick, Arlene A. Stecenko, Stefan Strack, Donald R. Cannon , Michelle Caudill , Angelo E. Canonico . 2000. Transfection of Nasal Mucosa with a Normal alpha1-Antitrypsin Gene in alpha1-Antitrypsin-Deficient Subjects: Comparison with Protein TherapyTransfection of Nasal Mucosa with a Normal alpha1-Antitrypsin Gene in alpha1-Antitrypsin-Deficient Subjects: Comparison with Protein Therapy. Human Gene Therapy 11:7, 1023-1032. [Abstract] [PDF] [PDF Plus]

17. Bei Li, Song Li, Yadi Tan, Donna B. Stolz, Simon C. Watkins, Lawrence H. Block, Leaf Huang. 2000. Lyophilization of cationic lipid-protamine-DNA (LPD) complexes. Journal of Pharmaceutical Sciences 89:3, 355-364. [CrossRef]

18. Yasushi RYUKE, Masaaki MIZUNO, Atsushi NATSUME, Jun YOSHIDA. 2000. Transduction Efficiency of Adenoviral Vectors into Human Glioma Cells Increased by Association with Cationic Liposomes. Neurologia medico-chirurgica 40:5, 256-260. [CrossRef]

19. Marie A. Printz , Ana Maria Gonzalez, Mark Cunningham, Dan-Ling Gu, Michael Ong, Glenn F. Pierce, Sharon Lea Aukerman . 2000. Fibroblast Growth Factor 2-Retargeted Adenoviral Vectors Exhibit a Modified Biolocalization Pattern and Display Reduced Toxicity Relative to Native Adenoviral VectorsFibroblast Growth Factor 2-Retargeted Adenoviral Vectors Exhibit a Modified Biolocalization Pattern and Display Reduced Toxicity Relative to Native Adenoviral Vectors. Human Gene Therapy 11:1, 191-204. [Abstract] [PDF] [PDF Plus]

20. Terrence Brann, Dawn Kayda , Russette M. Lyons, Pamela Shirley, Soumitra Roy, Michael Kaleko, Theodore Smith . 1999. Adenoviral Vector-Mediated Expression of Physiologic Levels of Human Factor VIII in Nonhuman PrimatesAdenoviral Vector-Mediated Expression of Physiologic Levels of Human Factor VIII in Nonhuman Primates. Human Gene Therapy 10:18, 2999-3011. [Abstract] [PDF] [PDF Plus]

21. Ben-Gary Harvey , Stefan Worgall , Scott Ely , Philip L. Leopold , Ronald G. Crystal . 1999. Cellular Immune Responses of Healthy Individuals to Intradermal Administration of an E1-E3- Adenovirus Gene Transfer VectorCellular Immune Responses of Healthy Individuals to Intradermal Administration of an E1-E3- Adenovirus Gene Transfer Vector. Human Gene Therapy 10:17, 2823-2837. [Abstract] [PDF] [PDF Plus]

22. Tord D. Alden , Debra D. Pittman, Gerald R. Hankins, Elisa J. Beres , Johnathan A. Engh, Subinoy Das, Sarah B. Hudson, Kelvin M. Kerns, David F. Kallmes, Gregory A. Helm . 1999. In Vivo Endochondral Bone Formation Using a Bone Morphogenetic Protein 2 Adenoviral VectorIn Vivo Endochondral Bone Formation Using a Bone Morphogenetic Protein 2 Adenoviral Vector. Human Gene Therapy 10:13, 2245-2253. [Abstract] [PDF] [PDF Plus]

23. Shailen R. Patel, Leonard Y. Lee, Charles A. Mack, Dean R. Polce, Tarek El-Sawy, Neil R. Hackett, Arzu Ilercil , Erica C. Jones, Rebecca T. Hahn, O. Wayne Isom, Todd K. Rosengart, Ronald G. Crystal . 1999. Safety of Direct Myocardial Administration of an Adenovirus Vector Encoding Vascular Endothelial Growth Factor 121Safety of Direct Myocardial Administration of an Adenovirus Vector Encoding Vascular Endothelial Growth Factor 121. Human Gene Therapy 10:8, 1331-1348. [Abstract] [PDF] [PDF Plus]

24. Catherine R. O'Riordan, Amy Lachapelle, Cristina Delgado, Vincent Parkes, Samuel C. Wadsworth, Alan E. Smith , Gillian E. Francis . 1999. PEGylation of Adenovirus with Retention of Infectivity and Protection from Neutralizing Antibody in Vitro and in VivoPEGylation of Adenovirus with Retention of Infectivity and Protection from Neutralizing Antibody in Vitro and in Vivo. Human Gene Therapy 10:8, 1349-1358. [Abstract] [PDF] [PDF Plus]

25. John H. Lee, Joseph Zabner, Michael J. Welsh . 1999. Delivery of an Adenovirus Vector in a Calcium Phosphate Coprecipitate Enhances the Therapeutic Index of Gene Transfer to Airway EpitheliaDelivery of an Adenovirus Vector in a Calcium Phosphate Coprecipitate Enhances the Therapeutic Index of Gene Transfer to Airway Epithelia. Human Gene Therapy 10:4, 603-613. [Abstract] [PDF] [PDF Plus]

26. Kazuhisa Otake, David L. Ennist, Kevin Harrod, Bruce C. Trapnell. 1998. Nonspecific Inflammation Inhibits Adenovirus-Mediated Pulmonary Gene Transfer and Expression Independent of Specific Acquired Immune ResponsesNonspecific Inflammation Inhibits Adenovirus-Mediated Pulmonary Gene Transfer and Expression Independent of Specific Acquired Immune Responses. Human Gene Therapy 9:15, 2207-2222. [Abstract] [PDF] [PDF Plus] 
27. Christopher D. Porada, Nam Tran, Martin Eglitis, Robert C. Moen, Lisa Troutman, Alan W. Flake, Yi Zhao, W. French Anderson, Esmail D. Zanjani. 1998. In Utero Gene Therapy: Transfer and Long-Term Expression of the Bacterial neor Gene in Sheep after Direct Injection of Retroviral Vectors into Preimmune FetusesIn Utero Gene Therapy: Transfer and Long-Term Expression of the Bacterial neor Gene in Sheep after Direct Injection of Retroviral Vectors into Preimmune Fetuses. Human Gene Therapy 9:11, 1571-1585. [Abstract] [PDF] [PDF Plus]

28. BRIAN C. O'CONNELL, C. DAVID LILLIBRIDGE, INDU AMBUDKAR, DAVID KRUSE. 1998. Somatic Gene Transfer to Salivary Glands. Annals of the New York Academy of Sciences 842:1 SALIVARY GLAN, 171-180. [CrossRef]

29. Steven E. Raper, Ziv J. Haskal, Xuehai Ye, Charles Pugh, Emma E. Furth, Guang-Ping Gao, James M. Wilson. 1998. Selective Gene Transfer into the Liver of Non-Human Primates with E1-Deleted, E2A-Defective, or E1-E4 Deleted Recombinant AdenovirusesSelective Gene Transfer into the Liver of Non-Human Primates with E1-Deleted, E2A-Defective, or E1-E4 Deleted Recombinant Adenoviruses. Human Gene Therapy 9:5, 671-679. [Abstract] [PDF] [PDF Plus]

30. Jay K. Kolls, Dinghua Lei, David Stoltz, Ping Zhang, Paul O. Schwarzenberger, Peng Ye, Greg Bagby, Warren R. Summer, Judd E. Shellito, Steve Nelson. 1998. Adenoviral-Mediated Interferon-gamma Gene Therapy Augments Pulmonary Host Defense of Ethanol-Treated Rats. Alcoholism: Clinical and Experimental Research 22:1, 157-162. [CrossRef]

31. Duane A. Sewell, Daqing Li, Ling Duan, Mary R. Schwartz, Bert W. O'Malley. 1997. Optimizing Suicide Gene Therapy for Head and Neck Cancer. The Laryngoscope 107:11, 1490-1495. [CrossRef]

32. Wei-Wei Zhang. 1997. Adenoviral vectors: development and application. Expert Opinion on Investigational Drugs 6:10, 1419-1457. [CrossRef]

33. Florence Dupuit, Thierry Chinet, Jean-Marie Zahm, Denis Pierrot, Jocelyne Hinnrasky, Herve Kaplan, Noël Bonnet, Edith Puchelle. 1997. Induction of a cAMP-Stimulated Chloride Secretion in Regenerating Poorly Differentiated Airway Epithelial Cells by Adenovirus-Mediated CFTR Gene TransferInduction of a cAMP-Stimulated Chloride Secretion in Regenerating Poorly Differentiated Airway Epithelial Cells by Adenovirus-Mediated CFTR Gene Transfer. Human Gene Therapy 8:12, 1439-1450. [Abstract] [PDF] [PDF Plus]

34. Cassandra Nyberg-Hoffman, Paul Shabram, Wei Li, Daniel Giroux, Estuardo Aguilar-Cordova. 1997. Sensitivity and reproducibility in adenoviral infectious titer determination. Nature Medicine 3:7, 808-811. [CrossRef]

35. ZHONGYUN DONG, XIULAN YANG, ISAIAH J. FIDLER. 1997. Neutralization of Endogenous Interferon- $\beta$ Increases the Efficiency of Adenoviral Vector-Mediated Gene TransductionNeutralization of Endogenous Interferon- $\beta$ Increases the Efficiency of Adenoviral Vector-Mediated Gene Transduction. Journal of Interferon \& Cytokine Researcb 17:7, 401-407. [Abstract] [PDF] [PDF Plus]

36. Deborah E. Sullivan, Srikanta Dash, Hong Du, Naoki Hiramatsu, Faruk Aydin, Jay Kolls, James Blanchard, Gary Baskin, Michael A. Gerber. 1997. Liver-Directed Gene Transfer in Non-Human PrimatesLiver-Directed Gene Transfer in Non-Human Primates. Human Gene Therapy 8:10, 1195-1206. [Abstract] [PDF] [PDF Plus]

37. Wim T. J. M. C. Hermens, Joost Verhaagen. 1997. Adenoviral Vector-Mediated Gene Expression in the Nervous System of Immunocompetent Wistar and T Cell-Deficient nude Rats: Preferential Survival of Transduced Astroglial Cells in nude RatsAdenoviral Vector-Mediated Gene Expression in the Nervous System of Immunocompetent Wistar and T Cell-Deficient nude Rats: Preferential Survival of Transduced Astroglial Cells in nude Rats. Human Gene Therapy 8:9, 1049-1063. [Abstract] [PDF] [PDF Plus]

38. Ming Zeng, George J. Cerniglia, Stephen L. Eck, Craig W. Stevens. 1997. High-Efficiency Stable Gene Transfer of Adenovirus into Mammalian Cells Using Ionizing RadiationHigh-Efficiency Stable Gene Transfer of Adenovirus into Mammalian Cells Using Ionizing Radiation. Human Gene Therapy 8:9, 1025-1032. [Abstract] [PDF] [PDF Plus]

39. Bo Lu, Howard J. Federoff, Yibin Wang, Lowell A. Goldsmith, Glynis Scott. 1997. Topical Application of Viral Vectors for Epidermal Gene Transfer. Journal of Investigative Dermatology 108:5, 803-808. [CrossRef]

40. Maryland Rosenfeld, Selwyn Vickers, David Raben, Minghui Wang, Lorenzo Sampson, Meizhen Feng, Elizabeth Jaffee, David Curiel. 1997. Annals of Surgery 225:5, 609-620. [CrossRef]

41. Jason G. Smith, Steven E. Raper, Eric B. Wheeldon, David Hackney, Kevin Judy, James M. Wilson, Stephen L. Eck. 1997. Intracranial Administration of Adenovirus Expressing HSV-TK in Combination with Ganciclovir Produces a Dose-Dependent, Self-Limiting Inflammatory ResponseIntracranial Administration of Adenovirus Expressing 
HSV-TK in Combination with Ganciclovir Produces a Dose-Dependent, Self-Limiting Inflammatory Response. Human Gene Therapy 8:8, 943-954. [Abstract] [PDF] [PDF Plus]

42. Zsuzsanna K. Zsengellér, Gregory P. Boivin, Steven S. Sawchuk, Bruce C. Trapnell, Jeffrey A. Whitsett, Raphael Hirsch. 1997. Anti-T Cell Receptor Antibody Prolongs Transgene Expression and Reduces Lung Inflammation after Adenovirus-Mediated Gene TransferAnti-T Cell Receptor Antibody Prolongs Transgene Expression and Reduces Lung Inflammation after Adenovirus-Mediated Gene Transfer. Human Gene Therapy 8:8, 935-941. [Abstract] [PDF] [PDF Plus]

43. Ronald K. Scheule, Judith A. St. George, Rebecca G. Bagley, John Marshall, Johanne M. Kaplan, Geoffrey Y. Akita, Kathryn X. Wang, Edward R. Lee, David J. Harris, Canwen Jiang, Nelson S. Yew, Alan E. Smith, Seng H. Cheng. 1997. Basis of Pulmonary Toxicity Associated with Cationic Lipid-Mediated Gene Transfer to the Mammalian LungBasis of Pulmonary Toxicity Associated with Cationic Lipid-Mediated Gene Transfer to the Mammalian Lung. Human Gene Therapy 8:6, 689-707. [Abstract] [PDF] [PDF Plus]

44. Canwen Jiang, Geoffrey Y. Akita, William H. Colledge, Rosemary A. Ratcliff, Martin J. Evans, Kathleen M. Hehir, Judith A. St. George, Samuel C. Wadsworth, Seng H. Cheng. 1997. Increased Contact Time Improves Adenovirus-Mediated CFTR Gene Transfer to Nasal Epithelium of CF MiceIncreased Contact Time Improves Adenovirus-Mediated CFTR Gene Transfer to Nasal Epithelium of CF Mice. Human Gene Therapy 8:6, 671-680. [Abstract] [PDF] [PDF Plus]

45. Ruth J. McDonald, Micheal J. Lukason, Otto G. Raabe, Don R. Canfield, Elizabeth A. Burr, Johanne M. Kaplan, Samuel C. Wadsworth, Judith A. St. George. 1997. Safety of Airway Gene Transfer with Ad2/CFTR2: Aerosol Administration in the Nonhuman PrimateSafety of Airway Gene Transfer with Ad2/CFTR2: Aerosol Administration in the Nonhuman Primate. Human Gene Therapy 8:4, 411-422. [Abstract] [PDF] [PDF Plus]

46. John A. Wagner, MD, PhD, Phyllis Gardner, MD. 1997. TOWARD CYSTIC FIBROSIS GENE THERAPY. Annual Review of Medicine 48:1, 203-216. [CrossRef]

47. Koji Kajiwara, Andrew P. Byrnes, Harry M. Charlton, Matthew J. A. Wood, Kathryn J. Wood. 1997. Immune Responses to Adenoviral Vectors During Gene Transfer in the BrainImmune Responses to Adenoviral Vectors During Gene Transfer in the Brain. Human Gene Therapy 8:3, 253-265. [Abstract] [PDF] [PDF Plus]

48. Yuji Heike, Minako Takahashi, Yumi Kanegae, Yumi Sato, Izumu Saito, Nagahiro Saijo. 1997. Interleukin-2 Gene Transduction into Freshly Isolated Lung Adenocarcinoma Cells with Adenoviral VectorsInterleukin-2 Gene Transduction into Freshly Isolated Lung Adenocarcinoma Cells with Adenoviral Vectors. Human Gene Therapy 8:1, 1-14. [Abstract] [PDF] [PDF Plus]

49. Johanne M. Kaplan, Donna Armentano, Tim E. Sparer, Susan G. Wynn, Pamela A. Peterson, Samuel C. Wadsworth, Kristen K. Couture, Sarah E. Pennington, Judith A. St. George, Linda R. Gooding, Alan E. Smith. 1997. Characterization of Factors Involved in Modulating Persistence of Transgene Expression from Recombinant Adenovirus in the Mouse LungCharacterization of Factors Involved in Modulating Persistence of Transgene Expression from Recombinant Adenovirus in the Mouse Lung. Human Gene Therapy 8:1, 45-56. [Abstract] [PDF] [PDF Plus]

50. Charles A. Mack, Wen-Ru Song, Heather Carpenter, Tom J. Wickham, Imre Kovesdi, Ben-Gary Harvey, Christopher J. Magovern, O. Wayne Isom, Todd Rosengart, Eric Falck-Pedersen, Neil R. Hackett, Ronald G. Crystal, Andrea Mastrangeli. 1997. Circumvention of Anti-Adenovirus Neutralizing Immunity by Administration of an Adenoviral Vector of an Alternate SerotypeCircumvention of Anti-Adenovirus Neutralizing Immunity by Administration of an Adenoviral Vector of an Alternate Serotype. Human Gene Therapy 8:1, 99-109. [Abstract] [PDF] [PDF Plus]

51. John C. Kucharczuk, Steven Raper, Ashraf A. Elshami, Kunjlata M. Amin, Daniel H. Sterman, Eric B. Wheeldon, James M. Wilson, Leslie A. Litzky, Larry R. Kaiser, Steven M. Albelda. 1996. Safety of Intrapleurally Administered Recombinant Adenovirus Carrying Herpes Simplex Thymidine Kinase DNA Followed by Ganciclovir Therapy in Nonhuman PrimatesSafety of Intrapleurally Administered Recombinant Adenovirus Carrying Herpes Simplex Thymidine Kinase DNA Followed by Ganciclovir Therapy in Nonhuman Primates. Human Gene Therapy 7:18, 2225-2233. [Abstract] [PDF] [PDF Plus]

52. Dominique J. Stephan, Zhi-Yong Yang, Hong San, Robert D. Simari, Carl J. Wheeler, Philip L. Felgner, David Gordon, Gary J. Nabel, Elizabeth G. Nabel. 1996. A New Cationic Liposome DNA Complex Enhances the Efficiency of Arterial Gene Transfer In VivoA New Cationic Liposome DNA Complex Enhances the Efficiency of Arterial Gene Transfer In Vivo. Human Gene Therapy 7:15, 1803-1812. [Abstract] [PDF] [PDF Plus] 
53. Theodore H. Welling, Beverly L. Davidson, Jennifer A. Zelenock, James C. Stanley, David Gordon, Blake J. Roessler, Louis M. Messina. 1996. Systemic Delivery of the Interleukin-1 Receptor Antagonist Protein Using a New Strategy of Direct Adenoviral-Mediated Gene Transfer to Skeletal Muscle Capillary Endothelium in the Isolated Rat HindlimbSystemic Delivery of the Interleukin-1 Receptor Antagonist Protein Using a New Strategy of Direct Adenoviral-Mediated Gene Transfer to Skeletal Muscle Capillary Endothelium in the Isolated Rat Hindlimb. Human Gene Therapy 7:15, 1795-1802. [Abstract] [PDF] [PDF Plus]

54. Jean Bennett, Stephen Pakola, Yong Zeng, Albert Maguire. 1996. Humoral Response after Administration of E1-Deleted Adenoviruses: Immune Privilege of the Subretinal SpaceHumoral Response after Administration of E1-Deleted Adenoviruses: Immune Privilege of the Subretinal Space. Human Gene Therapy 7:14, 1763-1769. [Abstract] [PDF] [PDF Plus]

55. James M. Stark, Raouf S. Amin, Bruce C. Trapnell. 1996. Infection of A549 Cells with a Recombinant Adenovirus Vector Induces ICAM-1 Expression and Increased CD-18-Dependent Adhesion of Activated NeutrophilsInfection of A549 Cells with a Recombinant Adenovirus Vector Induces ICAM-1 Expression and Increased CD-18-Dependent Adhesion of Activated Neutrophils. Human Gene Therapy 7:14, 1669-1681. [Abstract] [PDF] [PDF Plus]

56. PRINCIPAL INVESTIGATOR: Stephen L. Eck, CO-INVESTIGATORS: Jane B. Alavi, Abass Alavi, Alan Davis, David Hackney, Kevin Judy, Joan Mollman, Peter C. Phillips, Eric B. Wheeldon, James M. Wilson. 1996. Treatment of Advanced CNS Malignancies with the Recombinant Adenovirus H5.010RSVTK: A Phase I Trial. University of Pennsylvania Medical Center, PhiladelphiaTreatment of Advanced CNS Malignancies with the Recombinant Adenovirus H5.010RSVTK: A Phase I Trial. University of Pennsylvania Medical Center, Philadelphia. Human Gene Therapy 7:12, 1465-1482. [Abstract] [PDF] [PDF Plus]

57. Thasia Leimig, Malcolm Brenner, Jay Ramsey, Elio Vanin, Michael Blaese, Dagmar Dilloo. 1996. High-Efficiency Transduction of Freshly Isolated Human Tumor Cells Using Adenoviral Interleukin-2 VectorsHigh-Efficiency Transduction of Freshly Isolated Human Tumor Cells Using Adenoviral Interleukin-2 Vectors. Human Gene Therapy 7:10, 1233-1239. [Abstract] [PDF] [PDF Plus]

58. Margo R. Adesanya, Robert S. Redman, Bruce J. Baum, Brian C. O'Connell. 1996. Immediate Inflammatory Responses to Adenovirus-Mediated Gene Transfer in Rat Salivary GlandsImmediate Inflammatory Responses to Adenovirus-Mediated Gene Transfer in Rat Salivary Glands. Human Gene Therapy 7:9, 1085-1093. [Abstract] [PDF] [PDF Plus]

59. Sandeep K. Tripathy, Hugh B. Black, Eugene Goldwasser, Jeffrey M. Leiden. 1996. Immune responses to transgene-encoded proteins limit the stability of gene expression after injection of replication-defective adenovirus vectors. Nature Medicine 2:5, 545-550. [CrossRef]

60. Steven J. Sawchuk, Gregory P. Boivin, Laura E. Duwel, William Ball, Kevin Bove, Bruce Trapnell, Raphael Hirsch. 1996. Anti-T Cell Receptor Monoclonal Antibody Prolongs Transgene Expression Following Adenovirus-Mediated In Vivo Gene Transfer to Mouse SynoviumAnti-T Cell Receptor Monoclonal Antibody Prolongs Transgene Expression Following Adenovirus-Mediated In Vivo Gene Transfer to Mouse Synovium. Human Gene Therapy 7:4, 499-506. [Abstract] [PDF] [PDF Plus]

61. K. K. Wu, M.D, P. Thiagarajan, M.D. 1996. ROLE OF ENDOTHELIUM IN THROMBOSIS AND HEMOSTASIS. Annual Review of Medicine 47:1, 315-331. [CrossRef]

62. Stanley R. Riddell, Mark Elliott, Deborah A. Lewinsohn, Mark J. Gilbert, Linda Wilson, Sara A. Manley, Stephen D. Lupton, Robert W. Overell, Thomas C. Reynolds, Lawrence Corey, Philip D. Greenberg. 1996. T-cell mediated rejection of gene-modified HIV-specific cytotoxic T lymphocytes in HIV-infected patients. Nature Medicine 2:2, 216-223. [CrossRef]

63. Robert W. Wilmott, Raouf S. Amin, Carlos R. Perez, Susan E. Wert, Gary Keller, Gregory P. Boivin, Raphael Hirsch, Jaime de Inocencio, Patrick Lu, Shirley F. Reising, Soonpin Yei, Jeffrey A. Whitsett, Bruce C. Trapnell. 1996. Safety of Adenovirus-Mediated Transfer of the Human Cystic Fibrosis Transmembrane Conductance Regulator cDNA to the Lungs of Nonhuman PrimatesSafety of Adenovirus-Mediated Transfer of the Human Cystic Fibrosis Transmembrane Conductance Regulator cDNA to the Lungs of Nonhuman Primates. Human Gene Therapy 7:3, 301-318. [Abstract] [PDF] [PDF Plus]

64. Jian-Yun Dong, Danher Wang, Frederik W. van Ginkel, David W. Pascual, Raymond A. Frizzell. 1996. Systematic Analysis of Repeated Gene Delivery into Animal Lungs with a Recombinant Adenovirus VectorSystematic Analysis of Repeated Gene Delivery into Animal Lungs with a Recombinant Adenovirus Vector. Human Gene Therapy 7:3, 319-331. [Abstract] [PDF] [PDF Plus] 
65. Claude Sené, Abraham Bout, Jean-Luc Imler, Huguette Schultz, Jean-Marie Willemot, Vincent Hennebel, Chris Zurcher, Dinko Valerio, Didier Lamy, Andrea Pavirani. 1995. Aerosol-Mediated Delivery of Recombinant Adenovirus to the Airways of Nonhuman PrimatesAerosol-Mediated Delivery of Recombinant Adenovirus to the Airways of Nonhuman Primates. Human Gene Therapy 6:12, 1587-1593. [Abstract] [PDF] [PDF Plus]

66. John G. Hay, Noel G. McElvaney, Juan Herena, Ronald G. Crystal. 1995. Modification of Nasal Epithelial Potential Differences of Individuals with Cystic Fibrosis Consequent to Local Administration of a Normal CFTR cDNA Adenovirus Gene Transfer VectorModification of Nasal Epithelial Potential Differences of Individuals with Cystic Fibrosis Consequent to Local Administration of a Normal CFTR cDNA Adenovirus Gene Transfer Vector. Human Gene Therapy 6:11, 1487-1496. [Abstract] [PDF] [PDF Plus]

67. Jean-Thomas Vilquin, Benoit Guérette, Ikuo Kinoshita, Brigitte Roy, Marlyne Goulet, Claude Gravel, Raynald Roy, Jacques P. Tremblay. 1995. FK506 Immunosuppression to Control the Immune Reactions Triggered by First-Generation Adenovirus-Mediated Gene TransferFK506 Immunosuppression to Control the Immune Reactions Triggered by First-Generation Adenovirus-Mediated Gene Transfer. Human Gene Therapy 6:11, 1391-1401. [Abstract] [PDF] [PDF Plus]

68. Christopher Wilson, Mark A. Kay. 1995. Immunomodulation to enhance gene therapy. Nature Medicine 1:9, 887-889. [CrossRef]

69. Yiping Yang, Giorgio Trinchieri, James M. Wilson. 1995. Recombinant IL-12 prevents formation of blocking IgA antibodies to recombinant adenovirus and allows repeated gene therapy to mouse lung. Nature Medicine 1:9, 890-893. [CrossRef]

70. F. Dupuit, J.-M. Zahm, D. Pierrot, S. Brezillon, N. Bonnet, J.-L. Imler, A. Pavirani, E. Puchelle. 1995. Regenerating Cells in Human Airway Surface Epithelium Represent Preferential Targets for Recombinant AdenovirusRegenerating Cells in Human Airway Surface Epithelium Represent Preferential Targets for Recombinant Adenovirus. Human Gene Therapy 6:9, 1185-1193. [Abstract] [PDF] [PDF Plus]

71. Julie P. Katkin, Brian E. Gilbert, Claire Langston, Keith French, Arthur L. Beaudet. 1995. Aerosol Delivery of a $\beta$-Galactosidase Adenoviral Vector to the Lungs of RodentsAerosol Delivery of a $\beta$-Galactosidase Adenoviral Vector to the Lungs of Rodents. Human Gene Therapy 6:8, 985-995. [Abstract] [PDF] [PDF Plus]

72. Shinji Teramoto, Larry G. Johnson, Weihong Huang, Margaret W. Leigh, Richard C. Boucher. 1995. Effect of Adenoviral Vector Infection on Cell Proliferation in Cultured Primary Human Airway Epithelial CellsEffect of Adenoviral Vector Infection on Cell Proliferation in Cultured Primary Human Airway Epithelial Cells. Human Gene Therapy 6:8, 1045-1053. [Abstract] [PDF] [PDF Plus]

73. Martin C. Vincent, Bruce C. Trapnell, Robert P. Baughman, Susan E. Wert, Jeffrey A. Whitsett, Harriet S. Iwamoto. 1995. Adenovirus-Mediated Gene Transfer to the Respiratory Tract of Fetal Sheep In UteroAdenovirus-Mediated Gene Transfer to the Respiratory Tract of Fetal Sheep In Utero. Human Gene Therapy 6:8, 1019-1028. [Abstract] [PDF] [PDF Plus]

74. Mitchell J. Goldman, Leslie A. Litzky, John F. Engelhardt, James M. Wilson. 1995. Transfer of the CFTR Gene to the Lung of Nonhuman Primates with E1-Deleted, E2a-Defective Recombinant Adenoviruses: A Preclinical Toxicology StudyTransfer of the CFTR Gene to the Lung of Nonhuman Primates with E1-Deleted, E2a-Defective Recombinant Adenoviruses: A Preclinical Toxicology Study. Human Gene Therapy 6:7, 839-851. [Abstract] [PDF] [PDF Plus]

75. Frederik W. van Ginkel, Chongguang Liu, Jerry W. Simecka, Jian-Yun Dong, Terrence Greenway, Raymond A. Frizzell, Hiroshi Kiyono, Jerry R. McGhee, David W. Pascual. 1995. Intratracheal Gene Delivery with Adenoviral Vector Induces Elevated Systemic IgG and Mucosal IgA Antibodies to Adenovirus and $\beta$-GalactosidaseIntratracheal Gene Delivery with Adenoviral Vector Induces Elevated Systemic IgG and Mucosal IgA Antibodies to Adenovirus and $\beta$-Galactosidase. Human Gene Therapy 6:7, 895-903. [Abstract] [PDF] [PDF Plus]

76. Jeremy P. Springhorn, Joseph A. Madri, Stephen P. Squinto. 1995. Human capillary endothelial cells from abdominal wall adipose tissue: Isolation using an anti-pecam antibody. In Vitro Cellular \& Developmental Biology - Animal 31:6, 473-481. [CrossRef]

77. Jean-Luc Imler, Abraham Bout, Dominique Dreyer, Annick Dieterlé, Huguette Schultz, Dinko Valerio, Majid Mehtali, Andrea Pavirani. 1995. Trans-Complementation of E1-Deleted Adenovirus: A New Vector to Reduce the Possibility of Codissemination of Wild-Type and Recombinant AdenovirusesTrans-Complementation of E1-Deleted Adenovirus: A New Vector to Reduce the Possibility of Codissemination of Wild-Type and Recombinant Adenoviruses. Human Gene Therapy 6:6, 711-721. [Abstract] [PDF] [PDF Plus] 
78. Raouf Amin, Robert Wilmott, Yehuda Schwarz, Bruce Trapnell, James Stark. 1995. Replication-Deficient Adenovirus Induces Expression of Interleukin-8 by Airway Epithelial Cells In VitroReplication-Deficient Adenovirus Induces Expression of Interleukin-8 by Airway Epithelial Cells In Vitro. Human Gene Therapy 6:2, 145-153. [Abstract] [PDF] [PDF Plus]

79. Theodore Friedmann. 1995. Lesch-Nyhan disease as a model for central nervous system directed gene therapy. Mental Retardation and Developmental Disabilities Research Reviews 1:1, 49-55. [CrossRef]

80. Martin C. Vincent, Bruce C. Trapnell, Robert P. Baughman, Susan E. Wert, Jeffrey A. Whitsett, Harriet S. Iwamoto. 1995. Adenovirus-Mediated Gene Transfer to the Respiratory Tract of Fetal Sheep $<\mathrm{i}>$ In Utero $<$ i $>$. Human Gene Therapy 6:8, 1019. [CrossRef]

81. John F. Engelhardt, Leslie Litzky, James M. Wilson. 1994. Prolonged Transgene Expression in Cotton Rat Lung with Recombinant Adenoviruses Defective in E2aProlonged Transgene Expression in Cotton Rat Lung with Recombinant Adenoviruses Defective in E2a. Human Gene Therapy 5:10, 1217-1229. [Abstract] [PDF] [PDF Plus]

82. Ronald G. Crystal, Noel G. McElvaney, Melissa A. Rosenfeld, Chin-Shyan Chu, Andrea Mastrangeli, John G. Hay, Steven L. Brody, H. Ari Jaffe, N. Tony Eissa, Claire Danel. 1994. Administration of an adenovirus containing the human CFTR cDNA to the respiratory tract of individuals with cystic fibrosis. Nature Genetics 8:1, 42-51. [CrossRef]

83. Yiping Yang, Frederick A. Nunes, Klara Berencsi, Eva Gönczöl, John F. Engelhardt, James M. Wilson. 1994. Inactivation of E2a in recombinant adenoviruses improves the prospect for gene therapy in cystic fibrosis. Nature Genetics 7:3, 362-369. [CrossRef]

84. John F. Engelhardt, Richard H. Simon, Yiping Yang, Monica Zepeda, Sara Weber-Pendleton, Benjamin Doranz, Mariann Grossman, James M. Wilson. 1993. Adenovirus-Mediated Transfer of the CFTR Gene to Lung of Nonhuman Primates: Biological Efficacy StudyAdenovirus-Mediated Transfer of the CFTR Gene to Lung of Nonhuman Primates: Biological Efficacy Study. Human Gene Therapy 4:6, 759-769. [Abstract] [PDF] [PDF Plus] 